\title{
A method for assessing clot lysis
}

\author{
MARGARET HOWELL \\ From the Department of Haematology, St. George's Hospital \\ and Medical School, London
}

Clot lysis methods are used extensively in fibrinolytic work both for research into the physiology of the fibrinolytic system and for assay and standardization of enzymes. The following is a description of a simple method for measuring partial clot lysis using cheap and easily available apparatus and reagents. The method was first described by Blix in 1962 and has been adapted to suit the apparatus available and the subject being investigated.

The principle is as follows: a fibrin clot containing red blood cells is made and exposed to a fibrinolytic enzyme. As the clot lyses, red cells are released from it and the amount of lysis occurring in a given time can be found by measuring the number of cells released.

A clot of $1 \mathrm{ml}$. volume is made in a lusteroid tube measuring $11 \times 54 \mathrm{~mm}$. and its composition is shown diagrammatically in Figure 1. The basic components are fibrinogen $0.1 \mathrm{ml}$. (Kabi human fibrinogen, $1 \%$ solution) which is contaminated with plasminogen, thrombin

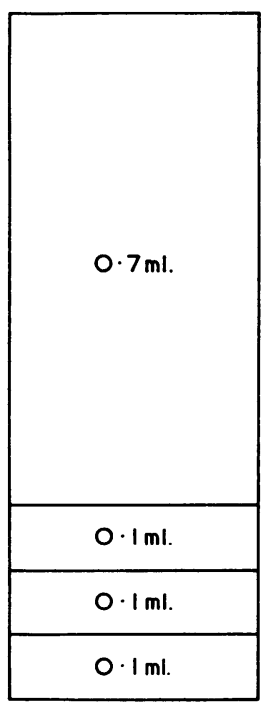

BUFFER SPACE

WASHED RED BLOOD CELLS

THROMBIN 50 UNITS $/ \mathrm{ml}$.

FIBRINOGEN $1 \%$ SOLUTION

FIG. 1. Diagram of the composition of the clot.
$0.1 \mathrm{ml}$. (Leo thrombin reagent 50 units $/ \mathrm{ml}$.), red bloo cells $0.1 \mathrm{ml}$. (packed platelet-free human red cells whiclo have been washed four times), and buffer 'space' $0.7 \mathrm{ml}-$ The clot is buffered to $p H \mathbf{H \cdot 2}$. Group 0 red cells are used because human serum fractions added to the clot mast contain blood group antibodies. The $0.7 \mathrm{ml}$. buffe 5 'space' is used for the addition of components of the fibrinolytic system so that their effect on clot lysis can be measured. Also any substance whose function in the fibrinolytic system is unknown can be substituted fo buffer 'space' and its activity as an inhibitor or an enzyme may be assessed.

To ensure that the red cells are distributed evenly throughout the clot, fibrinogen is added last, the tube stoppered and inverted rapidly three times. The tube is then left standing upside down on its stopper thus making it easy to extract the clot without breaking ito After at least 30 minutes the clot is gently transferred t\$ a petri dish containing physiological saline in order to remove any loose red cells. From the petri dish it is moved to a polythene container measuring $13 \times 30 \mathrm{~mm}$ ? with a push-on lid and having in it $2 \mathrm{ml}$. of fluid in which the clot floats. The nature of this fluid depends upon the experiment being carried out: it may be buffer, any. known component of the fibrinolytic system, or an substance whose effect on fibrinolysis one wishes to discover. Some examples will be given later to make this clearer.

The polythene container and clot are now placed in $37^{\circ} \mathrm{C}$. incubator on a rotating device. (Blix (1962) used $\mathrm{a}$ record player but a Matburn mixer is quite suitable. $\Phi$ As the clot lyses, red cells are released into the surrounding fluid and after a certain time the clot is lifted out of the container and the number of red cells in the surroundin fluid measured. To do this $0.5 \mathrm{ml}$. of the fluid containing the red cells is transferred to $4 \mathrm{ml}$. of $0.04 \%$ ammonium hydroxide and read in a spectrophotometer at a wave length of $542 \mathrm{~m} \mu$ against a blank in which $0.5 \mathrm{ml}$. of saline is used in place of the red cell suspension. The reading obtained on the spectrophotometer is converted to the percentage of total clot lysis by making a calibration curve with the same batch of red cells as was used in the clot, in which the $100 \%$ value is equivalent to all the red cells in the clot being released into the surrounding fluid. Each experiment is performed in duplicate and thळ mean percentage lysis taken in every case. Taking group of identical clots and surrounding fluid, the standar\% deviation at levels of lysis of $16 \%, 51 \%$, and $81 \%$ varied between 2 and 3. 


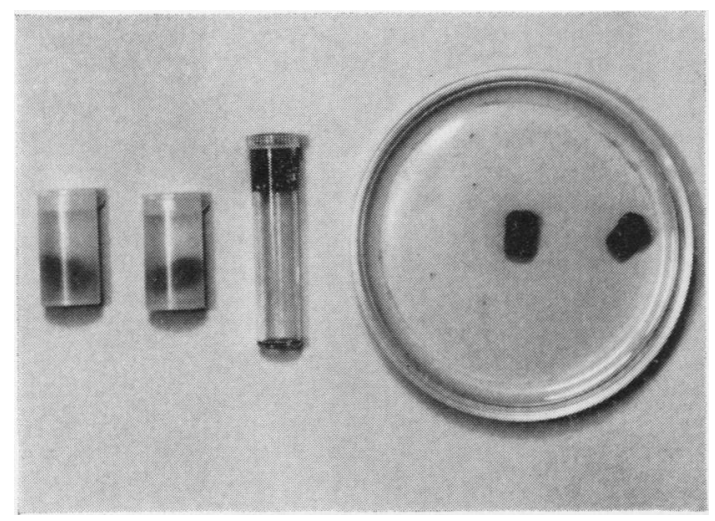

FIG. 2. Centre, clot in lusteroid container; right, clots in petri dish of saline; left, clots with surrounding fluid in polythene container.

To illustrate possible uses of the method some of the results obtained with it are shown below. The effect of human serum lipoproteins upon the various components of the human fibrinolytic system was being investigated. It was thought possible that lipoproteins might block plasminogen activation, or the action of plasmin itself, or that they might enhance the activity of the antiplasmins, or simply interfere mechanically with the diffusion of activator into a clot.

Low-density lipoprotein was obtained by highspeed centrifugation of normal non-lipaemic human serum. At the end of 14 hours at 40,000 r.p.m. this lipoprotein fraction is in the upper one sixth of the tube and can be pipetted off. A fibrinolytic enzyme was prepared by the method described by Blix (1962) in which venous blood with high activator content is taken from an arm rendered ischaemic by maintaining a sphygmomanometer cuff at $90 \mathrm{~mm}$. of mercury for five minutes. From the platelet-poor plasma the euglobulin fraction is precipitated using a strictly applied cold technique, resuspended in buffer, clotted with thrombin, the clot squeezed and transferred to a tube of buffer where it lyses, releasing 'lysed products' containing activator and plasmin into the buffer.

The clot lysis method was used to discover what proportion of the activity of the 'lysed products' was due to activation of the clot plasminogen and what proportion to the presence of plasmin, and the results are shown in Table I. In the first tube there was $90 \%$ lysis, but in the second tube, where there was sufficient epsilon-amino-caproic acid to inhibit plasminogen activation without interfering with the action of plasmin itself, there was $75 \%$ clot lysis. Under this experimental circumstance this suggested that most of the activity of the 'lysed products' was due to plasmin. The tube containing the streptokinase was included to show that the epsilon-aminocaproic acid was in fact capable of blocking the activation of plasminogen. No effect upon clot lysis could be demonstrated when the lipoprotein fraction was included in the clot (Table II), and the results in Table III show the inclusion of lipoprotein in the surrounding fluid to be equally ineffective.

\section{TABLE II}

EFFECT UPON LYSIS OF THE INCLUSION OF $\beta$ LIPOPROTEIN IN THE CLOT

\begin{tabular}{|c|c|c|c|}
\hline \multicolumn{2}{|c|}{ Clot ('Buffer Space') } & \multicolumn{2}{|l|}{ Surrounding Fluid } \\
\hline $\begin{array}{l}\text { B Lipoprotein } \\
(\mathrm{ml} .)\end{array}$ & Buffer (ml.) & $\begin{array}{l}\text { 'Lysed Products' } \\
(\mathrm{ml} .)\end{array}$ & Clot Lysis ( $\%)$ \\
\hline 0.7 & - & $2 \cdot 0$ & $55 \cdot 5$ \\
\hline 0.5 & $0 \cdot 2$ & $2 \cdot 0$ & 58.0 \\
\hline 0.4 & 0.3 & $2 \cdot 0$ & $57 \cdot 5$ \\
\hline $0 \cdot 2$ & 0.5 & $2 \cdot 0$ & 56.5 \\
\hline- & $0 \cdot 7$ & $2 \cdot 0$ & $56 \cdot 0$ \\
\hline
\end{tabular}

\section{TABLE III}

EFFECT UPON LYSIS OF $\beta$ LIPOPROTEIN IN FLUID SURROUNDING THE CLOT

Fluid Surrounding Clot of Constant Composition

\begin{tabular}{cccc}
\hline $\begin{array}{l}\text { B Lipoprotein } \\
(m l .)\end{array}$ & $\begin{array}{c}\text { 'Lysed Products's } \\
(\mathrm{ml} .)\end{array}$ & Buffer $(\mathrm{ml})$. & Clot Lysis (\%) \\
\hline 1.4 & 0.4 & 0.2 & 67.0 \\
1.0 & 0.4 & 0.6 & 66.0 \\
0.5 & 0.4 & 1.1 & 62.0 \\
0.2 & 0.4 & 1.4 & 65.5 \\
- & 0.4 & 1.6 & 62.5
\end{tabular}

TABLE I

EFFECT OF EPSILON-AMINO-CAPROIC ACID (E.A.C.A.) UPON ACTIVITY OF LYSED PRODUCTS

\begin{tabular}{|c|c|c|c|c|c|c|}
\hline \multicolumn{2}{|c|}{ Clot ('Buffer Space') } & \multicolumn{5}{|l|}{ Surrounding Fluid } \\
\hline $\begin{array}{l}\text { E.A.C.A. } 10^{-2} \mathrm{M} \\
(\mathrm{ml} .)\end{array}$ & Buffer $(m l)$. & $\begin{array}{l}\text { 'Lysed Products' } \\
(\mathrm{ml} .)\end{array}$ & $\begin{array}{l}\text { Streptokinase }(100 \mathrm{u} / \mathrm{ml} .) \\
(\mathrm{ml} .)\end{array}$ & $\begin{array}{l}\text { E.A.C.A. } 10^{-2} \mathrm{M} \\
(\mathrm{ml} .)\end{array}$ & Buffer $(\mathrm{ml} l)$. & Clot Lysis ( $\%)$ \\
\hline- & 0.7 & 0.4 & - & - & 1.6 & 90 \\
\hline 0.1 & 0.6 & 0.4 & - & 0.2 & 1.4 & 75 \\
\hline- & 0.7 & - & 1.0 & - & 1.0 & 55 \\
\hline 0.1 & 0.6 & - & 1.0 & 0.2 & 0.8 & $<1$ \\
\hline
\end{tabular}




\section{CONCLUSION}

This partial clot-lysis method seems particularly suitable for the type of investigation outlined. The components of the clot and the surrounding fluid may easily be varied, weaker enzymes than those necessary to bring about complete clot lysis can be used, and the duration of the experiment controlled. Possibly the greatest asset of the method is that it is objective: the final answer appears as a reading on the spectrophotometer and before this the worker has very little idea what the answer is going to be These advantages are shared by the $\mathrm{I}^{131}$ and fluor $\frac{\mathrm{o}}{\mathrm{C}}$ escein-tagged fibrinogen methods but the latter also require special apparatus.

This study was supported by grants from the St. George Hospital Research Fund and the Medical Research Council.

\section{REFERENCE}

Blix, S. (1962). Acta med. scand., suppl. 386. 